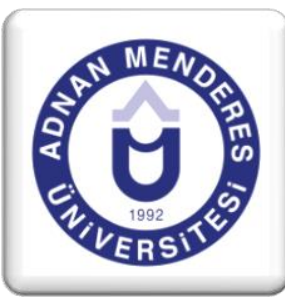

\section{Yabancıların Konut Talebinin Türkiye'deki Bölgesel Konut Talebi Üzerine Etkisi: Mekânsal Ekonometrik Analiz ${ }^{1}$}

Sinem Güler KANGALLI UYAR ${ }^{2}$, Emre KILIÇ ${ }^{3}$

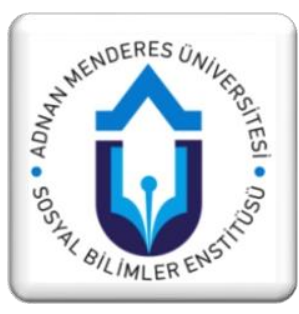

\title{
ÖZET
}

Çalışmanın amacı Türkiye'de konut satışlarında mekân etkisinin varlığını bölgesel düzeyde 2015 yılı için incelemektir. Çalışmada bölgesel konut talebi üzerinde belirleyici olabilecek ve literatürde sıklıkla kullanılan değişkenler bölgesel düzeydeki nüfus artış hızı, gelir dağılımı, konut fiyat endeksi ve Türkiye'de ikamet izni olan yabancı sayısıdır. Türkiye'deki bölgesel konut talebiyle ilgili olan diğer çalışmalardan farklı olarak, bu çalışmada ikamet izni olan yabancı sayısı, yabancıların konut talebinin bölgesel konut satışlarına olan etkisini incelemek amacıyla modele dâhil edilmiştir. Buna göre, Türkiye'de ikamet izni olan yabancı sayısı, konut fiyatları, nüfus artış hızı ve gelir dağılımının konut satışlarına olan etkisi Düzey 2 bölgeler bazında mekânsal ekonometrik modeller ile analiz edilmiştir. Mekânsal ekonometrik modellerden elde edilen tahmin sonuçları tüm değişkenlerin istatistiksel olarak anlamlı olduğunu göstermiştir. Ayrıca, analizde uygulanan mekânsal testler sonucunda incelenen yıl için Türkiye'de bölgesel konut satışlarında mekân etkisinin olduğu sonucuna ulaşılmıştır. Analiz sonucunda bölgesel konut talebi ve belirleyicileri arasındaki ilişkiyi açıklayan en iyi modelin ise, Mekânsal Durbin Modeli olduğuna karar verilmiştir. Mekânsal Durbin Modeli'nin tahmin sonuçlarına göre, nüfus artış hızı, gelir dağılımındaki adaletsizlik ve ikamet izni olan yabancı sayısındaki artış konut satışlarını arttırırken, konut fiyat endeksindeki yükseliş konut talebini düşürmektedir.

Anahtar Kelimeler; Bölgesel Konut Talebi, Yabancı Konut Talebi, Mekânsal Bağımlılık

Jel Kodları $\quad$; $21,018, F 22$

\section{The Effect Of Foreigners' Housing Demand On The Regional Housing Demand In Turkey: Spatial Econometrics Analysis}

\section{ABSTRACT}

The aim of the study is to examine the existence of the spatial effect on housing sales in Turkey at the regional level for 2015. The variables that can be determinant on regional housing demand in the study and which are frequently used in the literature are the population growth rate at the regional level, income distribution, the house price index and the number of foreigners who are allowed to reside in Turkey. Unlike other studies related to the regional housing demand in Turkey, the number of foreigners allowed to reside was included in the model to examine the effect of foreigners' housing demand on regional housing sales. According to this, the effect of number of foreign residents, housing price index, population growth rate and income distribution on housing sales in Turkey on the level of NUTS-2 is analyzed by spatial econometric models. The estimation results of the spatial econometric models show that all variables were statistically significant. In addition, the results of the spatial dependence tests show that the existence of spatial effect on regional housing sales in Turkey for the year examined. As a result of the analysis, it is decided that the best model explaining the relationship between regional housing demand and determinants was Spatial Durbin Model. The estimation results of this model indicate that an increase in population growth rate, income distribution inequality and the number of foreigners who are allowed to reside in Turkey increases housing sales, while the rise in the housing price index decreases housing sales.

Keywords; Regional Housing Demand, Foreigners' Housing Demand, Spatial Dependency

Jel Codes; C21,O18, F22

\footnotetext{
${ }^{1}$ Bu çalışma 29/07/2017 tarihinde, Adnan Menderes Üniversitesinde düzenlenen EUREFE'17 adlı kongrede sözlü metin olarak sunulmuştur. Aynı zamanda çalışmanın tam metni EUREFE'17 kongre kuruluna tam metin kitapçığında yayınlanmak üzere gönderilmiştir.

2 Pamukkale Üniversitesi, İ.İ.B.F., Ekonometri Bölümü, +90 (258) 296 2948, skangalli@pau.edu.tr

3 Pamukkale Üniversitesi, Sosyal Bilimler Enstitüsü, Ekonometri ABD, +90 (507) 470 1757, emmrekilic@ gmail.com
} 


\section{Giriş}

Konut fiyatlarındaki dalgalanmalar, hanehalkının yatırım ve tüketim kararlarını etkilemesinin yanı sıra ekonominin genelini etkilemesi açısından da oldukça önemlidir. Özellikle 2005 yılında ABD'de mortgage kredileriyle başlayan Mortgage Kredi Krizi, 2007 Ağustos ayı itibariyle hem konut piyasasında hem de finansal sistemde büyük sorunlara neden olarak 2007 sonrası yaşanan küresel finansal krizin en önemli nedenlerinden biri olmuştur. Küresel ekonomik krizin etkisi ile hem uluslararası piyasalarda hem de ulusal piyasalarda konut fiyatlarında gözlemlenen büyük değişiklikler, konut piyasasındaki istikrarın önemini bir kez daha ortaya koymuştur. Konut piyasasının hem doğrudan, hem de dolaylı olarak finansal istikrarı etkilemesi konut piyasasının takibini zorunlu kılmıştır. Konut fiyatlarındaki dalgalanmalar konut piyasasına ilişkin arz ve talep analizi ile incelenebilir, ancak kısa sürede konut arzının değişmeyeceği düşünülürse konut talebindeki değişimin konut fiyatlarındaki dalgalanmalarda daha belirleyici olduğu söylenebilir. Bu nedenle, konut talebini etkileyen faktörlerin incelenmesi konut fiyatlarındaki dalgalanmaların açıklanmasında oldukça önemlidir.

Konut talebini etkileyen faktörler, bireysel istekler ve toplumsal yapı olmak üzere iki açıdan ele alınabilir. Bireysel açıdan konut talebini etkileyen unsurlar kişilerin bireysel zevk ve tercihleri, ekonomik durumları, konut fiyatları ve diğer ilgili malların fiyatlarıdır. Toplumsal düzeyde konut talebinin belirlenmesinde ise, sosyo-demografik ve ekonomik unsurlar önemli rol oynamaktadır. Bu unsurlardan nüfus artış hızı, nüfusun yaş dağılımı,cinsiyet ve medeni durum, gelir dağılımı, eğitim seviyesi, göç ve kentleşme süreci, enflasyon, kredi koşulları ve faiz oranı ile gelir konut talebinin şekillenmesinde etkili olmaktadır.

Konut talebini etkileyen faktörler ülkeden ülkeye hatta bölgeden bölgeye farlılık gösterebilmektedir. Bu nedenle, bölgesel konut talebindeki farklılıkların incelenmesi ile ilgili yapılan araştırmalar son yıllarda önemli bir ilgi alanı haline gelmektedir. Özellikle de, bölgesel konut talepleri arasındaki ilişkiler çalışılan konular arasındadır (Akseki \& Türkcan, 2016; Mussa vd., 2017).

Bu çalı̧̧mada Türkiye'de Düzey 2 bölgeler bazında konut talebini etkileyen faktörlerin incelenmesi amaçlanmaktadır. Ayrıca bölgesel konut talebinde komşuluk ilişkilerinden kaynaklanan bir mekân etkisinin olup olmadığı mekânsal ekonometrik yöntemler ile araştırılmaktadır. Konut talebini etkileyen bir çok değişken olmasına rağmen bölgesel düzeyde veri bulmanın zorluğu ve eksikliği nedeniyle sadece nüfus artış hızı, Gini katsayısı, konut fiyat endeksi ve ikamet izni olan yabancı sayısı değişkenleri çalışmaya dâhil edilmiştir. Çalışmaya dâhil edilen bu değişkenler konut talebi üzerinde etkisi olabilecek ve literatürde kabul görmüş değişkenlerdir. Uluslararası literatürdeki ampirik çalışmalar, özellikle ikamet izni olan yabancı sayısının bölgesel konut talebi farklılığının oluşmasında ön plana çıkan önemli faktörlerden biri olduğunu göstermiş̧ir. $\mathrm{Bu}$ nedenle çalş̧mada, Türkiye'deki bölgesel konut talebiyle ilgili olan diğer çalışmalardan farklı olarak, konut talebinin diğer belirleyicileri ile birlikte ikamet izni olan yabancı sayısı, yabancıların konut talebinin bölgesel konut satı̧̧larına olan etkisini incelemek amacıyla modele dâhil edilmiştir. $\mathrm{Bu}$ açıdan bu çalışma konut sektörü ile ilgili olarak politika yapıcılara katkı sağlayacaktır. Çalışmanın buradan sonraki bölümünde çalışmaya dâhil ettiğimiz değişkenler ile konut talebi arasındaki ilişkiler ayrı ayıı açıklanacaktır. 


\subsection{Konut Talebi ile Açıklayıcı Değişkenler Arasındaki İlişki}

\subsubsection{Göç-Konut Talebi İlişkisi}

Göç, konut talebini belirleyen demografik faktörlerden biridir. Ekonomik gelişmeye ve yaşam standartlarının artmasına paralel olarak ülkelere yapılan göç oranları artmaktadır. Son yıllarda ülkemizde yaşam standartlarının yükselmesi de ülkemize göç eden yabancı nüfus oranını (ikamet izni olan) arttırmıştır. 2005 yılında ülkemizde ikamet eden yabancı sayısı 178.964 kişi iken 2016 yılı itibariyle bu rakam yaklaşık 2,5 katına çıkarak 461.217 kişiye ulaşmıştır (İçişleri Bakanlığı Göç İdaresi Genel Müdürlüğü). Son 11 yıl için ülkemizde ikamet izni alan yabancı sayısına ilişkin istatistikler Şekil 1'de verilmiştir (URL1).

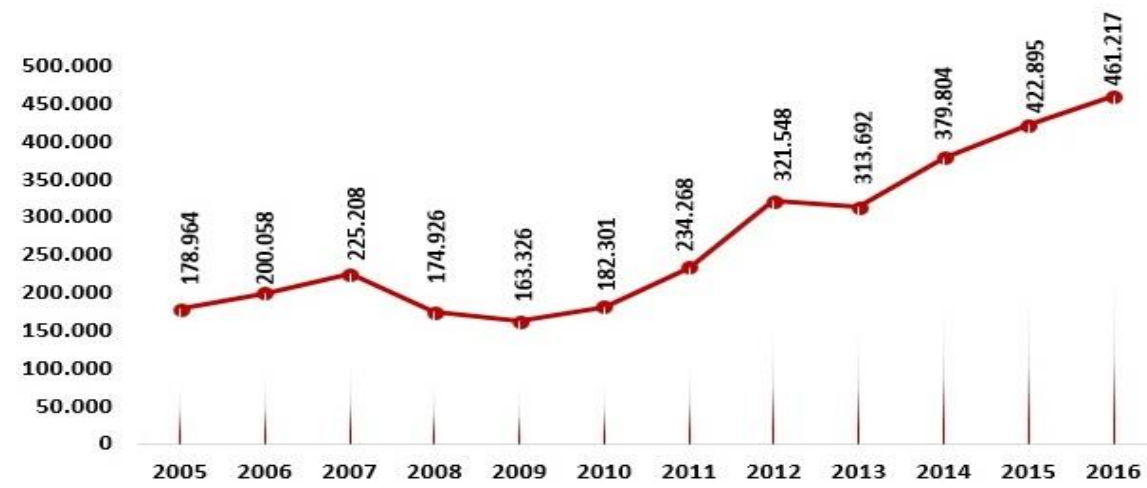

Şekil 1: Y1llara Göre İkamet İzni Bulunan Yabanc1 Sayıs1

Kaynak: T.C. İçişleri Bakanliği Göç Dairesi Genel Müdürlüğü

Göç oranlarının artması mevcut konut ihtiyacına ek konut ihtiyacı ortaya çıkartmaktadır. Artan talebe doğru orantılı olarak da konut satışları ve fiyatlarında artış yaşanmaktadır. Örneğin; Saiz (2007), yaptığı bir çalışmada, ABD'de göç edilen şehirlerde konut talebinin artıp artmadığını analiz etmiştir. Analiz sonuçları doğrultusunda göçün varış bölgelerindeki konut talebini artırdığı sonucuna ulaşmıştır. Bir diğer çalışmada Degen \& Fischer (2010), 2001 yılından 2006 yılına kadar İsviçre'de 85 ilçe için göçün ev fiyatları üzerindeki etkisini incelemişlerdir. Sonuçlar, bir bölgeye yapılan göçün konut fiyatlarını arttırdığını ortaya koymuştur. Ayrıca, ülkemizde 2012'de çıkarılan $\mathbf{6 3 0 2}$ sayılı Mütekabiliyet Yasası ile yabancıların konut satın alması kolaylaştırılmıştır. Daha öncelerde kanunlar yabancıların mülk edinme şartını karşılıklı işlem şartına bağlamaktaydı, yani yabancı uyruklu birinin Türkiye'de bir taşınmaz alabilmesi için onun ülkesinde de Türklerin aynı hakka sahip olması gerekiyordu. Çıkarılan bu yasa ile yabancılara konut satışının önü açılmıştır ve bu da konut talep eden yabancı sayısını arttırmıştır.

\subsubsection{Nüfus-Konut Talebi İlişkisi}

Nüfus, konut talebini etkileyen bir diğer demografik faktördür. Nüfus artışı bütün mal ve hizmetlere olan talebi artırdığı gibi konuta olan talebi de artırmaktadır. Arslan vd. (2013) yaptıkları bir çalışmada, Türkiye için nüfus artış hızı ve nüfus dağılımının konut talebi 
üzerindeki etkisini incelemişlerdir. Elde ettikleri sonuçlar konut talebini arttıran en önemli demografik faktörün nüfus olduğunu ve nüfus artış hızının konut talebini attıran bir faktör olduğunu ortaya koymuştur. Aynı zamanda nüfusun artması kentleşmeye yol açan bir etmendir ve dolaylı olarak kentleşme arttıkça konut satışlarının artması beklenir. Halıcıoğlu (2005), çalışmasında ARDL yöntemi kullanarak konut talebi fonksiyonunu tahmin etmeye çalışmıştır. Bu tahminden elde ettiği sonuçlar ile, konut talebi seviyesinin belirlenmesinde en önemli unsurlardan birisinin kentleşme düzeyi olduğunu ortaya koymuştur. Buna gore kentleşmenin artması konut talebini arttıran bir etmendir.

\subsubsection{Konut Fiyat Endeksi- Konut Satışları İlişsisisi}

Konut fiyat endeksi, Türkiye genelini temsil etmek üzere, tabakalanmış ortanca fiyat yöntemi kullanılarak hesaplanan fiyat endeksidir(URL2). Konut fiyat endeksinin hesaplanmasında, yapım yılına bakılmaksızın, satışa konu olan tüm konutlara ilişkin fiyat verileri kullanılmaktadır. Konut piyasasında konutun gerçek fiyatı satışın gerçekleşmesi ile oluştuğundan, söz konusu gerçek fiyatı temsil etmek üzere, bireysel konut kredisi talebiyle kredi veren kuruluşlara yapılan başvurular sırasında düzenlenen değerleme raporlarındaki konut değerleri kullanılmaktadır. Satışın gerçekleşerek kredinin kullandırılması şartı aranmamakta, değerlemesi yapılan tüm konutlar kapsama dâhil edilmektedir(URL2). Konut talebi de diğer mal ve hizmetlere olan talepte olduğu gibi fiyatlarda oluşan değişimin etkisi altındadır. Bu ilişki literatürde birçok kez araştırılmıştır ve konut fiyatlarının artmasının konut talebini azaltan bir etmen olduğu ortaya konmuştur. Lebe \& Akbaş (2014), çalışmalarında Türkiye'de konut talebinin kısa ve uzun dönem etkilerini ortaya koymayı ve konut politikalarına yön verebilecek bulguları elde etmeyi amaçlamışlardır. Bu amaçla, 1970-2011 dönemine ait yıllık veriler kullanarak yaptıkları analiz sonucunda, konut fiyatlarının konut talebini negatif yönde etkilediğini belirlemişlerdir. Bir diğger çalışmada, Elder \& Zumpano (1991), 968 aileyi içeren anket verilerini kullanarak "Michigan Üniversitesi Araştırma ve Araştırma Merkezi (SRC)" tarafından yürütülen, "Gelir Dinamikleri Panel Çalışması" nı baz alarak yapmış olduğu yatay kesit çalışmasında, konut fiyatları ile konut talebi arasında negatif yönde ilişki olduğunu tespit etmiştir.

\subsubsection{Gini Katsayısı- Konut Talebi İlişkisi}

Gini katsayısı gelir dağılımındaki adaletsizliği gösteren bir katsayıdır. 0 ile 1 arasında dağılır ve 1'e yaklaştıkça gelir dağılımındaki adaletsizliğin arttığını gösterir. $\mathrm{Bu}$ nedenle, bu katsayının 0'a yaklaşması istenen bir durumdur. Gelir dağılımı adaletsizliği azaldıkça, yani Gini katsayısı 0'a yaklaştıkça bireylerin konut taleplerinin artması beklenir (Öztürk \& Fitöz, 2009). Çünkü gelir dağılımın düzelmesi, düşük gelir seviyesine sahip kişilerin ellerine geçen ortalama gelirin artması anlamına gelmektedir. Başka bir deyişle, bireylerin gelir düzeyinin artmas1, bireylerin konut satın alabilecek ekonomik düzeye sahip olması anlamına gelmektedir. İnşaat Mühendisleri Odası'nın 2008 yılında hazırladığı konut raporunda, konut sektörünün durumuna, konut ihtiyacı tahminlerine ve konut politikasına ilişkin görüş ve önerilere yer verilmiştir. İlgili raporda gelir dağılımının adaletsiz olmasının konut sorununun daha da artmasına ve kişilerin konut satın almalarının zorlaşmasına neden olacağ belirtilmiştir. 


\section{Literatür Taraması}

Dünya'da konut talebi günümüzde araştırmacılar tarafından artan seviyede araştırılır hale gelmiştir. $\mathrm{Bu}$ bağlamda literatürde kabul görmüş ve konut talebi ile ilgili yapılmış çalışmalardan bazıları ana hatlarıyla şunlardır:

Saiz (2007), çalışmasında konut fiyatlarını açıklamada kullandığı diğer değişkenlerin konut fiyatlarına etkisinin yanı sıra göçün konut fiyatları üzerindeki etkisine yoğunlaşmıştır. $\mathrm{Bu}$ doğrultuda göçün yerel bir ekonomik etkisinin olup olmadığı ve ABD'de göç edilen şehirlerde kira ve konut fiyatlarının artıp artmadığını analiz etmiştir. Analizde kullanılan değişkenler, göçmen yoğunluğu, nüfus, kişi başına düşen gelir, işsizlik oranı, arazi miktarı, cinayet oranı, ocak ayı ortalama sıcaklık değerleri, temmuz ayı ortalama nispi nem miktarları ve eğitim derecesidir. Analizde EKK yönteminden yararlanılmıştır. Sonuçlar, göçün varış bölgelerindeki konut talebini artırdığını ve kısa vadede konut kiralarını arttırdığını göstermektedir. Ayrıca sonuçlar göçün Amerikan şehirlerinde yerel olarak ekonomik bir etkisinin olduğunu ortaya koymuştur.

Rivero (2008), çalışmasında 1995-2007 dönemi için İspanya ve onun özerk bölgelerinde konut fiyatlarının gelişimini incelemiştir. Analizde gayri safi yurt içi hasıla (GSYIH), nüfus, konut stoğu, ipotek faiz beklentileri ve göçmen sayısı verilerini kullanmıştır. Analiz metodu olarak regresyon analizini tercih etmiştir. Tahminler, konut fiyatlarındaki artışın \%14.75 ile temel değişkenler (gayri safi yurt içi hasıla, nüfus, konut stoğu, ipotek faiz beklentileri) tarafından belirlendiğini ortaya koymaktadır. Bu değer beklenen değere kıyasla konutların aşırı derecede değerlendiğine işaret etmektedir. Göçmen akışı hesaba katılırsa bu aşırı değerlenme, yüzde 7.37'ye düşmektedir. Yani göç edenlerin 1995'ten 2007'ye kadar İspanya'ya gelmesinin konut talebindeki ve konut fiyatlarındaki artışın belirlenmesinde önemli bir faktör olduğu, bu değerlenmenin büyük bir kısmının İspanya'ya yapılan göç tarafindan açıklandığı sonucuna ulaşılmıştır.

Degen \& Fischer (2010) yaptıkları bu çalışmada, İsviçre'de 2001 yılından 2006 yılına kadar 85 ilçe için konut fiyatlarını incelemişlerdir. Analizde EKK yönteminden yararlanmışlardır. Kullanılan değişkenler göçmenlerin nüfusa oranı, göçmenlere dayalı nüfus değişikliği, konut fiyatlarındaki değişiklik ve konut yapılabilecek boş alan miktarıdır. Sonuçlar, bir bölgeye yapılan göçün konut talebini ve dolayısıyla konut fiyatlarını arttırdığını ortaya koymuştur. Ayrıca konut fiyatlarındaki toplam fiyat artışının neredeyse üçte ikisinin göç etkisi tarafından açıklandığı sonucuna ulaşılmıştır.

Gonzalez \& Ortega (2013) çalışmalarında, 2000-2010 dönemi için İspanya'da konut fiyatları ve inşaat faaliyetlerini araştırmışlardır. Analiz yöntemi olarak regresyon analizi ve duyarlılık analizi kullanmışlardır. Analizde kullanılan değişkenler konut fiyatları, konut stoğu, nüfus, göçmen sayısı ve istihdam oranıdır. Bulgular, İspanya'nın 2000'li yıllardaki geniş göç dalgasının konut piyasasında hem fiyatlarda hem de konut miktarlarında büyük etkileri olduğunu göstermektedir. Genel olarak, göçün konut fiyatlarındaki artışın yaklaşık yüzde 25 'inden ve konut stoğundaki artışın yüzde 50'sinden sorumlu olduğu sonucuna varılmıştır.

Aung (2015), çalışmasında 2005 - 2010 döneminde ABD'de konut kira ve konut satış maliyetlerini etkileyen faktörleri araştırmıştır. Analizde regresyon analizinden yararlanmıştır. Bağımlı değişken, konut kira ve satış bedelindeki yıllık değişimdir. Analizde nüfus miktarı, yabanc1-doğumlu kişi sayısı, ev sahibi sayısı ve kiracı sayısına ilişkin tanımlayıcı istatistiklere yer verilmiştir ancak sadece temel açıklayıcı değişken olan belirli bir şehirde yabancı doğumlu kişi sayısının toplam nüfus payındaki artış miktarının konut kira ve satış fiyatlarına olan etkisi analiz edilmiştir. Çalışma sonuçları, yabancı doğum payı sayısının 1 puan artmasının, konut kira bedelini 1.103 puan ve konut fiyatların 2.111 puan arttırdığını 
ortaya koymuştur. $\mathrm{Bu}$ sonuç, $\mathrm{ABD}$ 'de incelenen dönem için konut talebinin artmasında toplam nüfus içindeki yabancı nüfus oranının önemli bir faktör olduğunu göstermektedir.

Kashnitsky \& Gunko (2016), çalışmalarında göçmenlerin Moskova'daki ilk konut seçimlerinin mekânsal varyasyonunu ve iç ve dış göçün konut fiyatları üzerine etkisini analiz etmişlerdir. Analizde poisson regresyon modelleri, varyans analizi ve mekânsal hiyerarşik ayrışma metodlarından yararlanmışlardır. Analizde kullanılan değişkenler bölgeler arası göç istatistikleri, uluslararası göç istatistikleri, ortalama konut satış fiyatları, aylık ortalama kira fiyatları, gayrimenkul fiyatları ve göç oranlarıdır. Elde edilen bulgular göçmenleri belirli sosyo-ekonomik duruma çeken bazı alanların bulunduğunu göstermektedir. Ayrıca sonuçlar, iç göçün konut fiyatlarında belirleyici olmadığını ancak yabancı göçmenlerin konut fiyatlarını etkileyen önemli bir faktör olduğunu ortaya koymuştur. Başka bir deyişle, Moskova'da yabancı göçmenler incelenen dönem için konut talebinin önemli bir belirleyicisidir.

Mussa vd. (2017), yaptıkları çalışmada ABD'de konut piyasasındaki konut kira ve fiyatlarını incelemişlerdir. Konut piyasasını mekânsal ekonometrik bağlamda incelemek için mekânsal Durbin modelini kullanmışlardır. Bağımlı değişken olarak konut kirası ve konut fiyatları kullanmışlardır. Bağımsız değişkenler ise göçmen sayısı, kişi başına düşen milli gelir, cinayet oran1, hırsızlık, nüfus, işsizlik oran1, nüfus yoğunluğu, göçmen yoğunluğu, ikamet izni olan yabancı nüfus sayısı ve kişi başına düşen arazi miktarıdır. Yapılan analiz sonucunda, bir şehire yapılan göçün, göçün yapıldığ şehir ve komşu şehirlerdeki konut talebini ve dolayısıyla konut kiraları ve fiyatlarını arttırdığı sonucuna ulaşılmıştır. Aynı zamanda bu sonuçlar göçün yapıldığı yerlerdeki uçuş sayısıyla da tutarlı çıkmıştır. Buna ek olarak hırsızlığın, kişi başına düşen arazi miktarının, konut arzının (izinler) ve işsizliğin artmasının kiraların düşmesine, gelirin artmasının ise kiraların artmasına neden olduğu sonucuna ulaşılmışıır.

Ulusal literatürde konut talebi teorik anlamda farklı açılardan ele alınmıştır. Ancak amprik çalışma sayısı oldukça azdır. Özellikle konut talebi ile göç arasındaki ilişkiyi araştıran çalışmaların az olmasının yanı sıra konut talebinde mekân etkisinin bölgesel incelendiği çalışma bulunmamaktadır. Bu bağlamda yaptığımız çalışma ilk olma niteliğini taşımaktadır. Ulusal literatürde konut talebi ile ilgili çalışmaları ana hatlarıyla inceleyecek olursak, Öztürk \& Fitöz (2009), Türkiye konut piyasasında konut arz ve talebinin belirleyicilerini regresyon analizi ve korelasyon testi yardımıyla incelemişlerdir. Analize kişi başına milli gelir, konut fiyatları ve faiz oranları değişkenleri dâhil edilmiştir. Elde edilen sonuçlar; kişi başına milli gelir, konut fiyatları ve faiz oranları ile konut talebi arasında pozitif yönlü bir ilişki; demografik faktörler ile konut talebi arasında ise önemsiz bir ilişki olduğunu göstermiştir. Bir diğer çalışmada Lebe \& Akbaş (2014), Türkiye'de konut talebinin kısa ve uzun dönem etkilerini ortaya koymayı amaçlamışlardır. Bu amaçla, 1970-2011 dönemine ait yıllık veriler kullanarak, Türkiye'nin konut talebini eşbütünleşme ve vektör hata düzeltme modeli (Vector Error Correction Model, VECM) ile analiz etmişlerdir. Kişi başı gelir, konut fiyatı, faiz oranı, sanayileşme, tarım sektöründe istihdam ve medeni durum gibi açıklayıcı değişkenler ile konut talebi arasındaki nedensellik ilişkisini VECM'e dayalı Granger nedensellik ve bootstrap Granger nedensellik incelemişlerdir. Yapılan analiz sonucunda, kişi başı gelir, medeni durum ve sanayileşmenin Türkiye'nin konut talebini pozitif yönde; konut fiyatları, faiz ve tarım sektöründe istihdamın ise negatif yönde etkilediği belirlenmiştir. Bununla birlikte Türkiye'nin konut talebini uzun dönemde en fazla etkileyen faktörün gelir olduğu tespit edilmiştir. Konut talebini en fazla etkiliyen ikinci ve üçüncü faktörün, sırasıyla, sanayileşme ve tarım sektöründe istihdam olduğu ortaya konmuştur. Bootstrap analizleri sonucunda ise kişi başı gelir, konut fiyatları, faiz oranı ve sanayileşmeden konut talebine doğru tek yönlü nedensellik ilişkisi olduğu belirlenmiştir. 
Konut talebini ele alan başka bir çalışma da Akseki \& Türkcan (2016), Türkiye'de Düzey-3 bölgeler (İBBS3) bazında iç göç ile konut ve işgücü piyasalarının ilişkilerini ele almışlardır. Bu kapsamda 2008 - 2013 dönemi için İBBS3 düzeyinde elde edilen veriler 1şı̆̆ında nedensellik olgusuna dayalı panel veri analizleri uygulamışlardır. Analizde kullanılan değişkenler; alınan göç, net göç, net göç hızı, işsizlik oranı ve konut satışları istatistikleridir. Elde edilen ampirik bulgulara göre, Türkiye'de söz konusu zaman aralığında bölgesel göç ile işsizlik oranı arasında bir nedensellik ilişkisine rastlanmazken, bölgesel göç ile konut satı̧ları arasında karşılıklı bir nedensellik ilişkisi tespit edilmiştir. Ulusal literatürde konut talebi ile ilgili yapılmış çalışmalara son bir örnek olarak Hatipoğlu ve Tanrıvermiş'in 2017'de yaptıkları çalışmayı verebiliriz. Bu çalışmada Türkiye'de arz ve talep açısından konut yatırım kararlarını etkileyen faktörleri değerlendirmişlerdir. Konut talebi açısından nüfus artışı, nüfusun yaşa göre dağılımı, göç, hanehalkı büyüklüğü gibi demografik, gayrisafi yurtiçi hasıla, kişi başı gelir, istihdam, büyüme oranı, faiz oranı ve konut kredileri gibi iktisadi değişkenleri genel olarak incelemişlerdir. Sonuç olarak, Türkiye'nin genç nüfusa sahip olması, çalışabilir nüfusun ülke nüfusu içindeki oranının yüksek olması ve hanehalkı büyüklüğünün azalmasının konuta talebi artıran en önemli faktörler olduğunu bulmuşlardır. Kişi başına gelirin yanında toplumdaki gelir dağılımının da konut harcamaları ve konut yatırımı tercihlerini doğrudan etkilediğini ve konut kredisi faiz oranında meydana gelen düşüşlerin hanehalkının konut satın alma talebini artırdığını ortaya koymuşlardır. Ayrıca Türkiye'nin büyüme hızı ile inşaat sektörünün büyüme hızı ve finans sektörünün konutlara kredi kullandırmasının birbiri ile ilişkili olduğu sonucuna ulaşmışlardır.

\section{Veri ve Metodoloji}

\subsection{Veri}

Türkiye'de Düzey 2 bazında konut talebi analiz edilmiştir ve analizler 2015 yılı için gerçekleştirilmiştir. Analizde, literatürde de kabul görmüş ve konut talebi üzerinde etkili olabilecek değişkenler olan nüfus artış hızı, Gini katsayısı, konut fiyat endeksi ve Türkiye'de ikamet izni olan yabancı sayısı kullanılmıştır. Analizde kullanılan Gini katsayısı, ikamet izni olan yabancı sayısı, konut satış ve nüfus artış hızı istatistikleri TUİK bölgesel veri tabanından, konut fiyat endeksine ilişkin veriler ise TCMB veri tabanından elde edilmiştir.

\subsection{Metodoloji}

Konut talebi gelir, nüfus artış hızı gibi temel değişkenlerin yanı sıra bölgeye özgü faktörlerden de etkilenebilmektedir. Belli bir bölgede konut talebinde meydana gelen bir şok komşusu olan başka bir bölgedeki konut talebini de etkileyebilmektedir. Coğrafi açıdan komşu olan bu bölgelerin konut talepleri arasındaki ilişki, mekânsal etkinin bölgesel konut talebinde önemli bir belirleyici olduğunu göstermektedir. Standart ekonometrik yöntemler komşuluk ilişkisi sonucu ortaya çıkan mekân etkisini dikkate almamaktadır, çünkü bu yöntemler gözlemlerin birbirinden bağımsız olduğu ve varyansın sabit olduğu varsayımları üzerine kurulu olan Gauss Markov teoremine dayanmaktadır. Gözlemler arasında bağımlılık olması durumunda, bu iki varsayım geçerliliğini yitirmektedir. Bu varsayımların ihlali de elde edilen sonuçların tutarsız ve sapmalı olmasına neden olacaktır. Başka bir deyişle, bölgesel çalışmalarda önemli bir belirleyici olan mekân etkisinin dikkate alınmaması dışlanmış değişken sapmasına neden olarak, analiz sonucunda elde edilen tahmin sonuçlarının sapmalı ve tutarsız olmasına neden olacaktır.

$\mathrm{Bu}$ noktada gözlemler arasındaki komşuluk ilişkilerini ve bu ilişkilerin neden olduğu sorunları dikkate alan mekânsal ekonometrik yöntemler geliştirilmiştir. Bölgesel, kent 
bilimleri vb. ile ilgili çalışmalarda yani konuma göre toplanılan veri ile yapılan analizlerde mekânsal ekonometrik yöntemler yerini almıştır. Konuma göre toplanılan bu veride mekânsal bağımlılık ve mekânsal heterojente olmak üzere iki çeşit sorun ortaya çıkabilmektedir. Mekânsal bağımlılık, belli bir mekânda ölçülen rassal değişkene ait değerler ile başka bir mekânda ölçülen rassal değişkene ait değerler arasında ilişki olmasıdır. Mekânsal heterojenite ise, değişkenler arasındaki fonksiyonel formun ve regresyon modeli parametrelerinin mekâna göre değişiklik göstermesi, başka bir deyişle veri seti boyunca sabit olmamasıdır (Anselin, 1988).

Mekânsal bağımlılı̆̆ın modele dâhil edilmesi aşamasında mekânsal ağırlık matrisinden yararlanılır. Mekânsal ağırlık matrisinin oluşturulmasında farklı yaklaşımlar söz konusudur. $\mathrm{Bu}$ yöntemlerden ilki kritik değer komşuluğudur. $\mathrm{Bu}$ yöntemde komşuluk ilişkisine belirlenen bir kritik değer (mesafe) ile karar verilir. Bu kritik değerin üzerindeki mesafeler için komşuluk ilişkisinin olmadığ 1 , kritik değerin aşağısındaki mesafeler için komuşuluk ilişkisinin olduğu söylenir. İkinci yöntem k. dereceden komşuluk ilişkisidir. Bu yöntemde ise komşuluk ilişkisine kaçıncı dereceden komşuluğun dâhil edileceğine karar verilir ve mekânsal ağırlık matrisi buna göre oluşturulur. Son yöntem ise, sınır komşuluğu yöntemidir. Bu yönteme göre mekânsal ağırlık matrisi iki coğrafi bölge, ülke, şehir vb. arasındaki coğrafi bir sınır komşuluğuna göre oluşturulur. Kısas alınan yönteme göre, eğer komşuluk ilişkisi mevcut ise "1", değilse "0" değeri verilir. Daha sonra standartlaştırma işlemi yapılarak mekânsal ağırlık matrisi oluşturulur. Mekânsal ağırlık matrisi $W_{i j}=g\left(d_{i j}\right)$ şeklindedir. $\mathrm{Bu}$ aşamadan sonra sorulması gereken soru mekânsal bir etkinin olup olmadığıdır. Mekân etkisinin varlığının tespit edilmesinde Moran's I Testi, Geary katsayısı, Cliff ve Ord istatistiği ile Lagrange çarpanı (LM) testleri mevcuttur. Pratikte en çok kullanılanı ise Moran's I testidir. Moran's I testine ilişkin formülasyon eşitlik 1'de gösterildiği gibidir:

$I=\frac{N}{S}\left(\frac{\varepsilon^{\prime} W_{\varepsilon}}{\varepsilon^{\prime} \varepsilon}\right)$

Burada $\varepsilon$ mekânsal etkilerin dâhil edilmediği doğrusal regresyon modelinden elde edilen kalıntılar, $N$ gözlem sayısı ve $S$ standartlaştırma faktörüdür.

Yapılan testler sonucu mekân etkisi olduğu sonucuna ulaşılırsa mekân etkisi iki şekilde modele dâhil edilebilir. Ya bağıml değişkenin mekânsal gecikmelisi modele bağımsız değişken olarak eklenir ya da mekân etkisi modelin hata terimine eklenir. Bağımlı değişkenin mekânsal gecikmelisinin modelde bağımsız değişken olarak yer aldığı durumda Mekânsal Gecikme Modeli elde edilir. Mekânsal gecikme modeli eşitlik 2'de olduğu gibi tanımlanabilir:

$y=\rho W y+X \beta+\varepsilon$

Burada $\rho$, bağımlı değişkenin mekânsal gecikmelisi için mekânsal otoregresif parametre, $W$ mekânsal ağırlık matrisi ve $X$ bağımsız değişkenler vektörüdür. $W y$, komşu bölgelerdeki bağımlı değişken y’nin ortalama mekânsal ağırlığını göstermektedir. Mekân etkisinin modelin hata terimine eklenmesi durumunda ise Mekânsal Hata Modeli kullanılır. Bu ilişkide başlangıç noktası eşitlik 3'te gösterilen, hiçbir mekân etkisinin bulunmadığı klasik doğrusal regresyon modelidir. Mekân etkisi bu modelin hata teriminin yapısına eşitlik 3.1'de gösterildiği gibi eklenir:

$y=X \beta+\varepsilon$ 
$\varepsilon=\lambda \mathrm{W} \varepsilon+\mathrm{u}$

Burada $\varepsilon \sim N\left(0, \sigma^{2} I\right)$ ve $\lambda-1$ ile 1 arasında yer almaktadır. $\lambda$ hata gecikmesi için mekânsal otoregresif katsayıdır. u ve $\varepsilon$ 'nın iliş̧kisiz olduğu ve u'nun sabit varyanslı olduğu varsayılır. Her iki etkinin de modelde olması durumunda yani mekân etkisinin modelin hem bağımlı değişkeninde hem de hata terimlerinde olması durumunda ise Mekânsal Durbin Modeli kullanılır. Mekânsal Durbin modeli eşitlik 4'te olduğu gibi tanımlanmaktadır:

$y=\rho W y+X \beta+\lambda W X \beta+u$

$u \sim N\left(0, \sigma^{2} I\right)$

Son olarak hangi mekânsal modelin mekânsal etkiyi en iyi açıklayan model olduğuna karar verilir. Bu aşamada LM testlerinden yararlanılır. Karar hiyarşisi şu şekildedir: İlk olarak her iki model için LM test istatistiklerinin anlamlılığına bakılır. Hangi modele ilişkin LM istatistiği anlamlı ise o modelin kullanılacağına karar verilir. Eğer iki model için de LM istatistikleri anlamlı ise karar işlemine testlerin robust versiyonları ile devam edilir. Robust testler bu durumda kullanılan alternatif testlerdir. Karar işlemi robust testler ile şu şekilde devam eder: Hangi modele ilişkin LM-robust sonuçları anlamlı ise o model kullanılır. Eğer iki model içinde LM-robust istatistikleri anlamlı ise, bu kez her iki etkinin de modelde bulunduğu Mekânsal Durbin Modeli'nin kullanılması gerektiğine karar verilir.

Mekân etkisinin varlığı durumunda EKK yöntemini kullanmak sapmalı ve tutarsız sonuçlar elde edilmesine neden olacaktır. Bu durumda mekân etkisini dikkate alan mekânsal modeller kullanılmalıdır. Bu modellerin tahmini maksimum olabilirlik yöntemi ile yapılmaktadır. Bu yöntemle tahmin edilen mekânsal modellerde en yüksek olabilirlik oranına (LR) sahip model diğerlerine göre ilişkiyi açıklamada en iyi modeldir.

\section{Ampirik Analiz}

Türkiye'de Düzey 2 bölgeler bazında konut talebi analiz edilmiştir. Analizde, literatürde de kabul görmüş ve konut talebi üzerinde etkili olabilecek değişkenler olan nüfus artış hızı, Gini katsayısı, konut fiyat endeksi ve Türkiye'de ikamet izni olan yabancı sayısı kullanılmıştır. Türkiye'deki bölgesel konut talebiyle ilgili olan diğer çalışmalardan farklı olarak, bu çalışmada konut talebinin diğer belirleyicileri ile birlikte ikamet izni olan yabancı sayısı, yabancıların konut talebinin bölgesel konut satışlarına olan etkisini incelemek amacıyla modele dâhil edilmiştir. Örneklemdeki bölgeler Tablo 1'de gösterilmektedir (URL3).

Tablo-1: Düzey 2 Bölgeler

\begin{tabular}{|l|l|l|l|}
\hline $\begin{array}{l}\text { Bölge } \\
\text { Kodları }\end{array}$ & İller & $\begin{array}{l}\text { Bölge } \\
\text { Kodları }\end{array}$ & \\
\hline TR10 & İstanbul & TR72 & Kayseri, Sivas, Yozgat \\
\hline TR51 & Ankara & TR81 & Zonguldak, Bartin, Karabuk \\
\hline TR31 & İzmir & TR82 & Cankiri, Kastamonu, Sinop \\
\hline TR21 & Edirde, Kirklareli, Tekirdag & TR83 & Samsun, Corum, Amasya, Tokat \\
\hline TR22 & Balikesir, Canakkale & TR90 & Artvin, Giresun, Gumushane, Ordu, \\
\hline
\end{tabular}




\begin{tabular}{|l|l|l|l|}
\hline & & & Rize, Trabzon \\
\hline TR32 & Aydin, Denizli, Mugla & TRA1 & Erzurum, Erzincan, Bayburt \\
\hline TR33 & $\begin{array}{l}\text { Afyonkarahisar, Kutahya, Manisa, } \\
\text { Usak }\end{array}$ & TRA2 & Agri, Ardahan, Kars, İgdir \\
\hline TR41 & Bursa, Eskisehir, Bilecik & TRB1 & Bingol, Elazig, Malatya, Tunceli \\
\hline TR42 & $\begin{array}{l}\text { Bolu, Kocaeli, Sakarya, Yalova, } \\
\text { Duzce }\end{array}$ & TRB2 & Van, Bitlis, Hakkari, Mus \\
\hline TR52 & Konya, Karaman & TRC1 & Kilis, Adiyaman, Gaziantep \\
\hline TR61 & Antalya, Burdur, İsparta & TRC2 & Diyarbakir, Sanliurfa \\
\hline TR62 & Adana, Mersin & TRC3 & Batman, Mardin, Siirt, Sirnak \\
\hline TR63 & Hatay, Kahramanmaras, Osmaniye & & \\
\hline TR71 & $\begin{array}{l}\text { Nevsehir, Nigde, Aksaray, } \\
\text { Kirikkale, Kirsehir }\end{array}$ & & \\
\hline
\end{tabular}

Kaynak: TÜİK, 2017

Türkiye'de ikamet izni olan yabancı sayısı, konut fiyat endeksi, nüfus artış hızı ve Gini katsayısının konut talebine olan etkisini analiz etmek için eşitlik 5'teki tam logaritmik model oluşturulmuştur.

$$
\text { lkonutsat }_{i}=\alpha_{0}+\alpha_{1} \text { lyabanci }_{i}+\alpha_{2} \text { lkonutfiyd }_{i}+\alpha_{3} \ln u f u s_{i}+\alpha_{4} \lg \text { ini }_{i}+\varepsilon_{i}
$$

Burada lkonutsatis konut talebini, lyabanci ikamet izni olan yabanc1 sayısın1, lkonutfiyat konut fiyat endeksini, lnufus nüfus artış hızını ve lgini Gini katsayısını ifade etmektedir. Ampirik analizin ilk aşamasında konut satışlarını açıklamak için oluşturulan modelde kullanılan değişkenlere ilişkin tanımlayıcı istatistikler elde edilmiştir. Sonuçlar Tablo 2'de yer almaktadır:

Tablo-2: Tanımlayıcı İstatistikler

\begin{tabular}{|l|l|l|l|l|}
\hline & Ortalama & Standart Sapma & Minimum Değer & $\begin{array}{l}\text { Maksimum } \\
\text { Değer }\end{array}$ \\
\hline konutsatis & 49589 & 49476.12 & 5323 & 239767 \\
\hline yabanci & 25012 & 38707.03 & 2516 & 199260 \\
\hline konutfiyat & 171.42 & 21.75 & 147.1 & 230.6 \\
\hline nufus & 9.88 & 9.18 & -6.34 & 26.72 \\
\hline gini & .36 & .02 & .32 & .41 \\
\hline
\end{tabular}

Kaynak: Yazarların Hesaplamaları, 2017

Tablo 2'ye göre 2015 y1lında Düzey 2 bölgeler bazında ortalama 49589 konut satılmıştır. Bölgesel bazda en az konut TRA2 koduyla Ağrı, Ardahan, Kars ve Iğdır'ın olduğu bölgede satılmıştır. En yüksek konut satışı ise İstanbul'da gerçekleşmiştir. Bölgesel olarak ortalama 25012 yabancı Türkiye'de ikamet izni almıştır ve yabancıların ikamet yeri seçiminde en çok tercih ettikleri yer İstanbul'dur. Konut fiyat endeksine ilişkin istatistikleri incelediğimizde en yüksek değere sahip bölgenin TR10 kodlu bölge olan İstanbul olduğu görülmektedir. 2015 yılında nüfus artış hızı bölgesel olarak ortalama \%9.88 olarak gerçekleşmiştir. Nüfus artış hızının en yüksek olduğu bölge Bolu, Kocaeli, Sakarya, Yalova ve Düzce illerinin 
bulunduğu TR42 kodlu bölgedir. Nüfus artış hızının en düşük olduğu bölge ise Ağn, Ardahan, Kars ve Iğdır illerinin bileşiminden oluşan TRA2 kodlu bölgedir. Son olarak gelir dağglımındaki adaletsizliği gösteren Gini katsayısına ilişkin istatistikler incelendiğinde 2015 yılında gelir dağılımının en adaletsiz olduğu yani yüksek gelirli kesim ile düşük gelirli kesim arasındaki farkın en geniş olduğu bölge Diyarbakır ve Şanlıurfa illerinin bulunduğu TRC2 kodlu bölgedir. Gelir dağılımındaki adaletsizliğin en az olduğu bölge ise Kilis, Adiyaman ve Gaziantep illerinden oluşan TRC1 kodlu bölgedir. Değişkenlere ilişkin özet bilgiler incelendikten sonra değişkenler arasındaki ilişkiyi ortaya koymak amacı ile Tablo 3'te gösterildiği gibi korelasyon matrisi oluşturulmuştur.

Tablo 3. Korelasyon Matrisi

\begin{tabular}{|l|l|l|l|l|l|}
\hline & konutsatis & gini & konutfiyat & yabanci & nufus \\
\hline konutsatis & 1 & .193 & .501 & .927 & .582 \\
\hline gini & .193 & 1 & .102 & .128 & -.055 \\
\hline konutfiyat & .501 & .102 & 1 & .588 & .360 \\
\hline yabanci & .927 & .128 & .588 & 1 & .432 \\
\hline nufus & .582 & -.055 & .360 & .432 & 1 \\
\hline
\end{tabular}

Kaynak: Yazarların Hesaplamaları, 2017

Tablo 3'teki korelasyon matrisi incelendiğinde açıklayıcı değişkenler arasında yüksek derecede ilişkinin olmadığı söylenebilir. Bağımlı değişken olan konutsatis değişkeni ile açıklayıcı değişkenler arasındaki ilişkiler incelendiğinde ise, konutsatis ve yabanci değişkenleri arasındaki ilişki katsayısının yaklaşık 0.93 olduğu görülmektedir. Bu sonuç, yabancı sayısının konut talebini etkileyebilecek önemli bir değişken olduğunun göstergesi olabilir.

Çalışmanın buradan sonraki bölümde çalışmada kullanılan veriler Düzey 2 bazında bölgesel veriler olduğu için bölgesel konut talebinde mekân etkisinin olup olmadığını incelenmiştir. Bu bağlamda Moran's I istatistiği hesaplanmıştır. Bu aşamada kullanılan ağırlık matrisi (W), 26 bölgenin komşuluk ilişkileri incelenerek elde edilmiştir. Ağırlık matrisinin hesaplanması aşamasında kullanılan komşuluk matrisi ise iki bölgenin birbirine coğrafi sınırının olup olmaması ile belirlenmiştir. Eğer bölgeler arası sınır komşuluğu mevcut ise 1 değilse 0 değeri verilmiştir. Son olarak standartlaştırma işlemi yapılarak $26 \times 26$ boyutundaki mekânsal ağırlık matrisi oluşturulmuştur. Değişkenler arasında mekânsal bağımlılığın olup olmadığını test etmek için Moran's I testi uygulanarak test sonucuna Tablo 4'te yer verilmiştir:

Tablo 4. Mekânsal Bağımlılık Testi

\begin{tabular}{|l|l|}
\hline & Test İstatistiğ \\
\hline Moran's-I & $.271^{* *}$ \\
\hline $\begin{array}{l}* *: \% 1 \text { 'deki anlamlılığ } 1, * *: \% 5 \text { 'deki anlamlılığ1, *: \%10 daki anlamlılı̆̆ ifade } \\
\text { etmektedir. }\end{array}$ \\
\hline
\end{tabular}

Kaynak: Yazarların Hesaplamaları, 2017

Moran's I testi sonucunda incelenen yıl için Türkiye'de bölgesel konut satışlanında mekân etkisinin ya da mekânsal bağımlılığın olduğu sonucuna ulaşılmıştır. Başka bir deyişle, belli bir bölgedeki konut satışlarında meydana gelen bir şok komşuluk ilişkisi nedeniyle başka bir bölgedeki konut satışlarını etkileyebilmektedir. Bu aşamadan sonra bölgesel konut satışları için oluşturulan model, Mekânsal Hata Modeli (SEM), Mekânsal Gecikme Modeli (SLM) ve 
Mekânsal Durbin Modeli (SDM) ile tahmin edilmiştir. Mekânsal modellere ilişkin test sonuçları listelenmeden önce hangi mekânsal modelin kullanılacağına karar vermek için LM testleri uygulanmıştır. Testlere ait sonuçlar Tablo 5 'te yer almaktadır.

Tablo 5. LM Test Sonuçları

\begin{tabular}{|c|c|}
\hline & Test İstatistiği \\
\hline LM-Gecikme & $2481.35 * * *$ \\
\hline Robust LM-Gecikme & $4329.95 * * *$ \\
\hline LM-Hata & $36.29 * * *$ \\
\hline Robust LM-Hata & $323000 * * *$ \\
\hline
\end{tabular}

Kaynak: Yazarların Hesaplamaları, 2017

Test sonuçlarına göre LM-Gecikme ve LM-Hata testlerinin birlikte anlamlı olduğu görülmektedir. $\mathrm{Bu}$ nedenden dolayı karar verme sürecine testlerin robust versiyonları ile devam edilmelidir. Robust LM testleri incelendiğinde Robust LM-Gecikme ve Robust LMHata testlerinin de birlikte anlamlı olduğu görülmüsşür. Bu nedenle mekânsal etkinin, modelin hem bağımlı değişkeninde hem de hata terimlerinde olması durumunda kullanılan Mekânsal Durbin Modeli'nin kullanılmasına karar verilmiştir. Üç mekânsal modele ve EKK modeline ilişkin test sonuçları Tablo 6' da gösterilmektedir:

Tablo 6. Tahmin Sonuçları

\begin{tabular}{|c|c|c|c|c|}
\hline Değişken & $\begin{array}{c}\text { Mekânsal } \\
\text { Gecikme Modeli }\end{array}$ & $\begin{array}{l}\text { Mekânsal Hata } \\
\text { Modeli }\end{array}$ & $\begin{array}{l}\text { Mekânsal Durbin } \\
\text { Modeli }\end{array}$ & EKK Modeli \\
\hline yabanci & $\begin{array}{l}.639 * * * \\
(9.73)\end{array}$ & $\begin{array}{l}.718 * * * \\
(10.34)\end{array}$ & $\begin{array}{l}.740 * * * \\
(8.94)\end{array}$ & $\begin{array}{c}1.112 * * * \\
(10.70)\end{array}$ \\
\hline konutfiyati & $\begin{array}{c}-1.060 * * * \\
(-2.29) \\
\end{array}$ & $\begin{array}{c}-1.647 * * * \\
(-3.81)\end{array}$ & $\begin{array}{c}-1.471 * * * \\
(-2.56) \\
\end{array}$ & $\begin{array}{c}-257.071 \\
(-1.45)\end{array}$ \\
\hline nufus & $\begin{array}{l}.175 * * * \\
(4.31)\end{array}$ & $\begin{array}{l}.199 * * * \\
(5.42)\end{array}$ & $\begin{array}{l}.184 * * * * \\
(3.30)\end{array}$ & $\begin{array}{c}1361.161^{* * * *} \\
(3.56)\end{array}$ \\
\hline gini & $\begin{array}{c}2.972 * * * \\
(4.16) \\
\end{array}$ & $\begin{array}{c}3.160 * * * \\
(6.56)\end{array}$ & $\begin{array}{c}3.457 * * * \\
(3.80)\end{array}$ & $\begin{array}{c}228745.6 \\
(1.69) \\
\end{array}$ \\
\hline sabit & $\begin{array}{l}10.749 \\
(4.38)\end{array}$ & $\begin{array}{c}52.904 \\
(.11) \\
\end{array}$ & $\begin{array}{l}-3.123 \\
(-.26) \\
\end{array}$ & $\begin{array}{c}-31199.61 \\
(-.56)\end{array}$ \\
\hline Rho & $\begin{array}{l}.178^{*} \\
(1.95)\end{array}$ & & & \\
\hline Lambda & & $\begin{array}{l}.996 * * * \\
(21.57)\end{array}$ & & \\
\hline Log-Likelihood & -5.580 & -2.197 & -1.786 & \\
\hline F-istatistiği & $24.10 * * *$ & $32.33 * * *$ & $12.78 * * *$ & $58.37 * * *$ \\
\hline
\end{tabular}

Kaynak: Yazarların Hesaplamaları, 2017

İlk olarak elde edilen modellerin anlamlı olup olmadıkları F-istatistikleri yardımıyla incelenmiştir ve dört modelin de \%95 güvenilirlik düzeyinde anlamlı olduğunu sonucuna ulaşılmıştır. Karşılaştırma yapmak amacı ile tahmin edilen ve mekânsal etkiyi dikkate 
almayan EKK modeline ilişkin sonuçlar incelendiğinde sadece ikamet izni olan yabancı sayısı ve nüfus artış hızı değişkenlerinin anlamlı olduğu görülmüştür. Ancak EKK modeline ilişkin bu sonuçlar sapmalı ve tutarsızdır. Çünkü EKK yöntemi gözlemlerin birbirinden bağımsız olduğu ve varyansın sabit olduğu varsayımları üzerine kurulu olan Gauss Markov Teoremi'ne dayanmaktadır. Gözlemler arasında mekânsal bağımlılığın olması bu iki varsayımın ihlal edilmesine ve buna paralel olarak parametre tahminlerinin sapmalı ve tutarsız olmasına, normalde anlamlı olan bir katsayının anlamsız, anlamsız bir katsayının da anlamlı çıkmasına neden olabilmektedir. Bu nedenle EKK modeline ilişkin test sonuçlarının yorumlanması doğru olmayacaktır. Bu durumda mekân etkisini de dikkate alan mekânsal ekonometrik yöntemler kullanılmalıdır. Moran's I testi sonucunda mekânsal otokorelasyonun var olduğu sonucuna ulaşılmıştı ve hangi mekânsal modelin kullanılacağına karar vermek için uygulanılan LM Testleri sonucunda ise bölgesel konut talebi ve belirleyicileri arasındaki ilişkiyi açıklayan en iyi modelin, Mekânsal Durbin Modeli olduğuna karar verilmişti. Bu nedenle sadece Mekânsal Durbin Modeli'ne ilişkin test sonuçları yorumlanacaktır. Mekânsal Durbin Modeli'nin tahmin sonuçlarına göre, nüfus artış hızındaki \%1'lik artış konut talebini \%0.17 arttırmaktadır. Ulusal literatürdeki Arslan, Ceritoğlu \& Kanık (2013) çalışması da bu sonuçları desteklemektedir. Gini katsayısına ilişkin sonuçlar incelendiğinde, gelir dağılımındaki adaletsizlikte \%1'lik artışın konut taleplerini \%3.45 arttırdığı sonucuna ulaşılmıştır. Ancak beklenen sonuç Gini katsayısı ile konut satışları arasındaki ilişkinin negatif yönlü olması yönünde idi. Bu sonuç ise şu şekilde açılanabilir: Türkiye'de son yıllarda yüksek gelirli kesime yönelik lüks konut yapımında ciddi oranda artış yaşanmıştır. İnşaat şirketleri kar marjının yüksek olması nedeniyle yüksek gelirli kesime yönelik konut arzına yönelmişlerdir. $\mathrm{Bu}$ da konut satışlarında ve konut arzında düşük gelirli kesime yönelik bir dışlama yaratmıştır. Bu dönemde düşük gelirli konut satın alamamasına rağmen, lüks konutlar ile gerçekleştirilen konut arzı yüksek gelirli kesim tarafından talep edilmiştir ve aslında gelir dağılımındaki adaletsizliğin artmasıyla düşmesi gereken konut satışlarını arttırmıştır. Buna ek olarak konut satışları ve Gini katsayısı arasındaki pozitif ilişki, yüksek gelirli kesimin yatırım amaçlı ve ihtiyacından fazla konut satın alması ile adaletsiz bir gelir dağılımı ortamında konut satışlarının artması şeklinde açıklanabilir. Konut satışlarındaki yabancı etkisi incelendiğinde, Türkiye'de ikamet izni olan yabancı sayısındaki \%1'lik artışın konut satışlarını \%0.74 arttırdığı sonucuna ulaşılmıştır. Literatürde göç-konut ilişkisini inceleyen Degen \& Fischer (2010) ve Saiz (2007) çalışmları da bu sonuçları desteklemektedir. Son olarak konut fiyat endeksindeki \%1'lik artışın konut talebini \%1.47 düşürdüğü sonucuna ulaşılmıştır. Lebe \& Akbaş (2014), Elder \& Zumpano (1991) çalışmaları konut talebi ve konut fiyat endeksi arasındaki ilişkiyle ilgili sonuçları desteklemektedir.

\section{SONUÇ}

Çalışmada, Türkiye'de ikamet izni olan yabancı sayısı, konut fiyat endeksi, nüfus artış hızı ve Gini katsayısının konut satışlarına olan etkisi 2015 yılı için Düzey 2 bölgeler bazında mekânsal ekonometrik modeller ile analiz edilmiştir. İncelenen yıl için Türkiye'de bölgesel konut satışlarında mekân etkisinin olduğu sonucuna ulaşılmıştır. Başka bir deyişle, belli bir bölgedeki konut satışlarında meydana gelen bir şok komşuluk ilişkisi nedeniyle başka bir bölgedeki konut satışlarını etkileyebilmektedir. Mekansal bağımlılık testlerinin uygulanması ile elde edilen sonuçlar bölgesel konut talebi ve belirleyicileri arasındaki ilişkiyi açıklayan en iyi modelin Mekânsal Durbin Modeli olduğunu göstermiştir. Mekânsal Durbin Modeli'nin tahmin sonuçlarına göre, nüfus artış hızı, Gini katsayısı ve ikamet izni olan yabancı sayısındaki artış konut talebini arttırırken, konut fiyat endeksindeki yükseliş konut talebini 
düşürmektedir. İktisadi beklentilere göre Gini katsayısı yani gelir dağılımı adaletsizliğindeki artışın konut talebini düşürmesi beklenmektedir. Ancak analiz sonuçlarına göre ilişkinin pozitif çıkması, inşaat şirketlerinin, kar marjının yüksek olması nedeniyle, yüksek gelirli kesim için konut arzına yönelmesi ve yüksek gelirli kesimin yatırım amaçlı ve ihtiyacından fazla konut satın alması ile açıklanabilir. Analize dahil edilen diğer açıklayıcı değişkenler ile konut talebi arasındaki ilişkilerin yönü ise, iktisadi beklentilere uygun olarak elde edilmiştir. 


\section{KAYNAKÇA}

AKSEKI, U., \& TÜRKCAN, B. (2016). "Türkiye'de Bölgesel Göç, Konut Ve İşgücü Piyasaları Üzerine Panel Nedensellik Analizler". International Congress of Management Economy and Policy (Proceedings Book). ICOMEP 2016.

ANBARCI, M., GIRAN, Ö., TÜRKAN, Y. S., \& MANISALI, E. (2012). "Ürün Olarak Konut Kavrami Ve Türkiye'deki Konut Satişlarinin Ürün Hayat Eğrisi Yaklaşimiyla Değerlendirilmesi". e-Journal of New World Sciences Academy, 178-188.

ANSELIN, L. (1988). "Spatial Econometrics: Methods and Models", Kluwer Academic Publishers: Dordrecht/Boston/London.

ARSLAN, Y., CERITOĞLU, E., \& KANIK, B. (2013). "The Effects of Demographic Changes on the Long Term Housing Demand in Turkey". Munich Personal RePEc Archive.

AUNG, T. K. (2015). "The Effects of Immigration on Housing Market in The United States". Undergraduate Thesis Paper (Unpublished Master Thesis).

DEGEN, K., \& FISCHER, A. M. (2010). "Immigration and Swiss House Prices". Swiss National Bank Working Papers.

ELDER, H. W., \& ZUMPANO, L. V. (1991). "Tenure Choice, Housing Demand and Residential". The Journal Of Real Estate Research.

GOETZMANN, W., \& VALAITIS, E. (2006). "Simulating Real Estate in the Investment Portfolio: Model Uncertainty and Inflation Hedging". Social Science, Yale ICF Working Paper.

GONZALEZ, L., \& ORTEGA, F. (2013). "Immigration And Housing Booms: Evidence From Spain". Journal Of Regional Science, 37-59.

HALICIOGLU, F. (2005). "The Demand For New Housing In Turkey: An Application Of Ardl Model". 2005 Business and Economics Society International Conference. Arizona.

HATIPOĞLU, Ü., \& TANRIVERMIŞ, H. (2017). "Türkiye'de Arz ve Talep Açısından Konut Yatırım Tercihlerini Etkileyen Faktörlerin Değerlendirilmesi". Bankacılar Dergisi, 49-75.

KASHNITSKY, I., \& GUNKO, M. (2016). "Spatial variation of in-migration to Moscow: Testing the effect of housing market". Cities, 30-39.

LEBE, F., \& AKBAŞ, Y. E. (2014). "Türkiye'nin Konut Talebinin Analizi: 1970-2011". Atatürk Üniversitesi İktisadi ve İdari Bilimler Dergisi, 57-83.

MUSSA, A., NWAOGU, U. G., \& POZO, S. (2017). "Immigration and housing: A spatial econometric analysis". Journal of Housing Economics, 13-25.

ÖZTÜRK, N., \& FITÖZ, E. (2009). "Türkiye'de Konut Piyasasinin Belirleyicileri: Ampirik Bir Uygulama". ZKÜ Sosyal Bilimler Dergisi, 21-46.

RIVERO, S. S. (2008). "Immigration And House Prices In Spain" . Regional Economy, Working Paper.

SAIZ, A. (2007). "Immigration and housing rents in American cities". Journal of Urban Economics, 345-371.

URL1. T.C. IÇ̧ŞSLERİ BAKANLIĞI GÖÇ DAIRESİ GENEL MÜDÜRLÜĞÜ. Ağustos 12, 2017 tarihinde http://www.goc.gov.tr/icerik6/ikamet-izinleri_363_378_4709_icerik adresinden alındı

URL2. Türkiye Cumhuriyet Merkez Bankası. Ağustos 14, 2017 tarihinde http://www.tcmb.gov.tr/wps/wcm/connect/26e3c246-8d58-4b75-a5cf09ae6fa18543/KFEYontem.pdf?MOD=AJPERES adresinden alınd 1

URL3. Türkiye İstatistik Кититu(TUIK). Ağustos 23, 2017 tarihinde https://biruni.tuik.gov.tr/bolgeselistatistik/\# adresinden alındı 